\title{
Improving the quality of mechanical tests based on experiments with the use of reference objects and inter-laboratory comparisons
}

\author{
Tadeusz Szymczak ${ }^{1}$ Andrzej Wierzejski² ${ }^{2}$ Jacek Górecki ${ }^{3}$
}

\begin{abstract}
:
The aim of the paper is to present the research procedure to improve performing mechanical tests. The article shows the results from experiments carried out with the use of reference objects and inter-laboratory comparisons. Details of the research technique for determining the mechanical parameters of strength screws and testing technical springs, are presented. The tensile characteristics of the screw material are provided with the indication of all the necessary mechanical parameters important for engineering practice, i.e. within the elastic and elastic-plastic range. In the case of the spring, the values of its deflection are presented, resulting from multiple loading to a specific force value and subsequent unloading. The obtained results are compared with the properties of the reference object using mathematical statistics and the requirements of the standard on proficiency testing. As a result, the competences of the research teams in the scope of performing the mentioned types of mechanical tests are confirmed.
\end{abstract}

\section{KEYWORDS:}

mechanical tests; inter-laboratory comparison; quality improvement; competences

\section{Introduction}

Mechanical tests represent the kind of experiments, performed on products or specimens. Selecting the research object depends on the aim of the test. If it is to determine the mechanical parameters of the material, the tests should be carried out using specimens. This makes it possible to determine: Young's modulus, proportional limit (PL), elastic limit (EL), yield point (YP), ultimate tensile strength (UTS), relative elongation after fracture (RE), and relative reduction of area (RR) $[1,2]$. When the response of the finished product under loading is followed, mechanical tests should be carried out without any changes in the geometry and material-structural features of the selected object $[3,4]$. It is also worth taking care with the manner of mounting of the object, which should reflect the operational conditions. This is so the test results can be directly used for the working conditions [5]. Despite the difference in shapes and sizes of tested objects, tests determining mechanical parameters and following the behaviour of the finished product can be easily proven as the types of loading are the same, both: static and fatigue. However, some differences may be related to the values of the loading velocity, amplitude and frequency of the input signal. Depending on the experimental assumptions, the mechanical tests can be conducted up to the fracture of a tested object or a specific value of the physical quantity collected.

1 Motor Transport Institute, ul. Jagiellońska 80, 03-301 Warszawa, e-mail: tadeusz.szymczak@its.waw.pl, orcid id: 0000-0003-2533-7200

2 Motor Transport Institute, ul. Jagiellońska 80, 03-301 Warszawa, e-mail: andrzej.wierzejski@its.waw.pl

${ }^{3}$ Motor Transport Institute, ul. Jagiellońska 80, 03-301 Warszawa, e-mail: jacek.gorecki@its.waw.pl 
The tested object in a form of specimens requires several stages, such as: (a) indicating representative zones, (b) designing the specimen, (c) arrangement of the specimens in the regions for examining material behaviour, (d) manufacturing the specimens using a specific technology [6-8].

In the case of components, laboratory activities should be directed to the design and production of a mounting system, which, unlike the method - enabling the introduction of specimens by means of dedicated grips and faces controlled by the hydraulic or pneumatic system is multi-element and diverse, depending on the shape and the tested object dimensions.

The measurements of physical quantities, which are the parameters of the loading signal and the reactions of the tested object, are followed by means of specific types of measuring sensors. The force cell and displacement sensor as measuring subassemblies integrated with the testing machine are used during experiments conducted with both types of tested objects. Uni-axial or biaxial extensometers are employed for determining elongation or shortening in tests carried out on specimens. Their use in trials where the test object is in a form of a finished product is practically impossible globally, but possible locally, as long as the shape of the tested component enables the sensor to be mounted, and the test result from the selected area will bring us closer to a reliable assessment of the tested product. When component response is determined based on displacement/deformation maps the Digital Image Correlation (DIC) technique is recommended [9-11].

Although tests with the use of specimens and finished products give different results, nevertheless they are very complementary. Their reciprocity results from the combination of the data collected. In the case of the test on specimens, it is possible to evaluate the material examined and to improve the design, while the test on finished products approaches the quality of the manufactured product. This way, complete data can be obtained supporting operating conditions, diagnostics as well as expert activity in order to indicate the causes of possible failures. For these reasons, the evaluation of the technical condition of the product should be carried out with the use of both types of tested objects. Mechanical tests require not only knowledge of the mechanics of materials and structures [12-16] and requirements from the document of general instructions $[1,17,18]$, but also the relevant experience [19-22]. Experience is usually gathered over many years of practice by performing tests on various structural materials as well as specimens and tested objects in different shapes. A helpful procedure to verify or improve professional competences in the field of mechanical tests is experiment with the use of reference materials [23] or inter-laboratory tests. The first of these experiments can be carried out independently, as a direct analysis of the results - by comparing them with mechanical parameters assigned to the tested object with a certificate or feature. Inter-laboratory tests require at least two participants, conducting tests according to a specific instruction, in the same environmental conditions, using the same type of examined object and test parameters of measuring sensors enabling the recording of the physical quantities from the beginning of the test up to its final stage.

\section{Tested objects and details of the experimental technique}

\subsection{Strength screws, test methodology and evaluation criteria}

An example of a tested object - classified as a reference component - is the strength screw (Fig. 1a). Apart from the typical geometrical features, such as thread diameter, thread pitch and length, there is a combination of numbers on the screw head (Figs. 1b, c), which are directly related to the mechanical parameters of the structural material used to manufacture the element. The first one represents the 0.01 th value of ultimate tensile strength, while the second reflects the tenth part ( 0.8 in this case) of the ratio expressed by the proportion of the yield strength to ultimate tensile strength. In the case of a strength screw in technical class 8.8, the number designation should be expanded as follows: ultimate tensile strength (UTS) $=800 \mathrm{MPa}$, yield point $(\mathrm{YP})=640 \mathrm{MPa}$. 
(a)

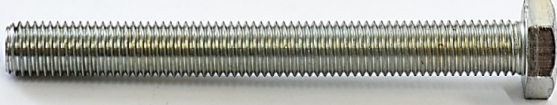

(b)

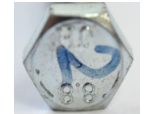

(c)

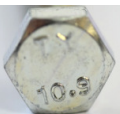

Fig. 1. Screw with metric thread (a) and screw heads with the examples of the strength classes: 8.8 (b), 10.9 (c)

Specimens for determining the mechanical parameters of the screw material should have the same features, especially in the measuring zone, as the specimens used in the tensile test $[1,17]$ (Fig. 2). It is related to the requirement for the homogeneous stress state of the measuring section. There can be no material discontinuities or geometrical imperfections, because their presence affects the obtained results, giving unreliable conclusions. Depending on the technical capabilities of the test stands, the gripping parts may be threaded or machined, resulting in manufacturing a specimen. Nevertheless, with respect to the requirements $[17,18]$ concerning the testing of the structural material used for the production of screws, one should strive to use certified washers and nuts (Fig. 3) up to the specified value of the screw thread diameter and the loading.

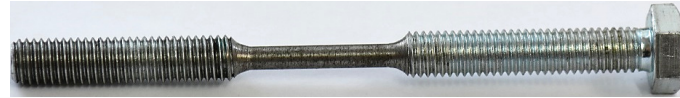

Fig. 2. A specimen made of a screw of 8.8 technical class

The components shown in Figure 3: the washer and the strength nut are directly used in the region at the screw head and in the opposite threaded zone (Fig. 4). In the test, they play the role of resistance surfaces, cooperating with the surfaces of the installing zone, located in specialized strength sleeves (Figs. 5a, b). Special grips, as the washers and strength nuts, are designed for a specific loading value. In the discussed case of assembly components, it was a value of $150 \mathrm{kN}$ (Fig. 5c).

Strength tests of the screw material should be carried out in accordance with the provisions of the following standards:

a) PN-EN ISO 898-1 entitled: "Mechanical properties of fasteners made of carbon steel and alloy steel - Part 1: Screws, screws and studs with specified property classes - Coarse thread and fine pitch thread" [17],

b) PN-EN ISO 3506-1 entitled: "Fasteners - Mechanical properties of corrosion-resistant stainless steel fasteners - Part 1: Screws, screws and studs with specified grades and property classes" [18],

c) PN-EN ISO 6892-1 entitled: "Metallic materials - Tensile test - Part 1: Test method at room temperature" [1].

In the discussed case, the tests were carried out at room temperature with the use of the 8802 INSTRON servo-hydraulic testing machine, operating in a closed feedback loop. The test was performed with the use of a monotonically increasing displacement signal with a velocity of $0.4 \mathrm{~mm} / \mathrm{min}$. The strain changes were recorded using a uni-axial extensometer. The expanded uncertainty of the force measurement was $0.6325 \mathrm{kN}$ (probability approx. 95\%, extension factor $\mathrm{k}=2$ ).

(a)

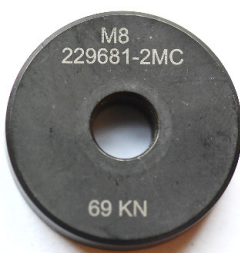

(b)

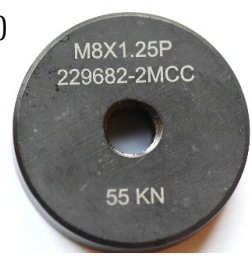

(c)

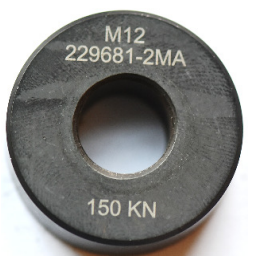

(d)

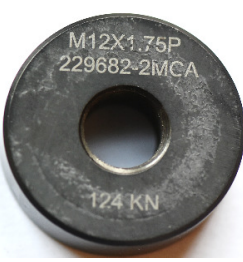

Fig. 3. Washer and nut for testing the structural material of strength screws in the tensile test, in various technical classes: (a) and (b) as well as (c) and (d) respectively for the M8 $\times 1.25$ screw up to the load value of $69 \mathrm{kN}$ (washer) and $55 \mathrm{kN}$ (nut); for M12 × 1.75 screw up to a load of $150 \mathrm{kN}$ (washer) and $124 \mathrm{kN}$ (nut) 


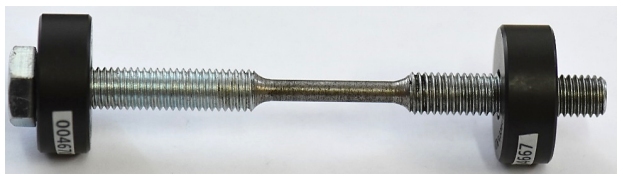

Fig. 4. Specimen with a washer and nut for mounting the object in the grips shown in Fig. 5

(a)

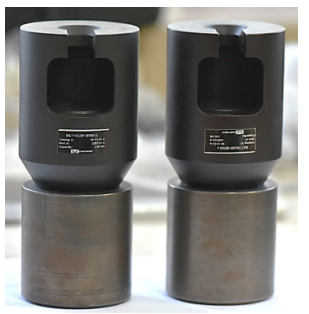

(b)

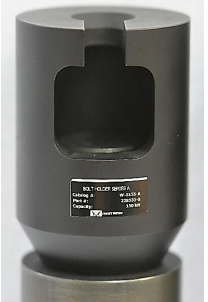

(c)

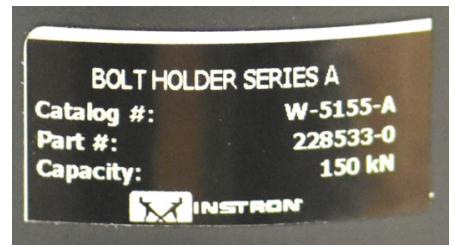

Fig. 5. Specialist grips for determining the mechanical parameters of the strength screws:

(a) general view, (b) view of the area for mounting the tested object, (c) nameplate with catalogue number, component number and loading capacity

Selected results from tensile tests, such as the value of yield point, ultimate tensile strength, relative elongation after fracture and relative reduction of area, were compared with the requirements of PN-EN ISO 898-1 [17].

\subsection{Technical spring, testing methodology and evaluation criteria}

Technical springs are a type of component for which it is practically impossible to manufacture specimens. Therefore, these elements are tested without any interference with the material and construction features. The main purpose of the experiment with the use of a technical spring is to determine the reaction of the tested object under loading, obtaining the values of the force, shortening or elongation. In the case of inter-laboratory comparisons, the aim of the test may be more detailed, indicating a displacement value as a physical quantity used to evaluate the competences of the participating teams.

In the discussed case, the test object was a ground cylindrical (coil) spring with the number of turns - 15 (Fig. 6a). The dimensions of the spring were as follows: height was of $162 \mathrm{~mm}$, diameter reached $48 \mathrm{~mm}$, wire diameter was equal to $6 \mathrm{~mm}$.

(a)

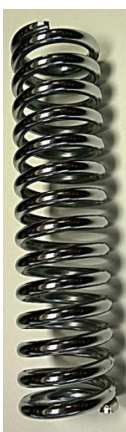

(b)

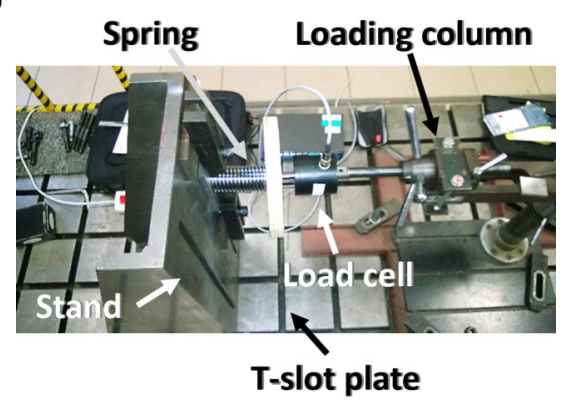

(c) Upper

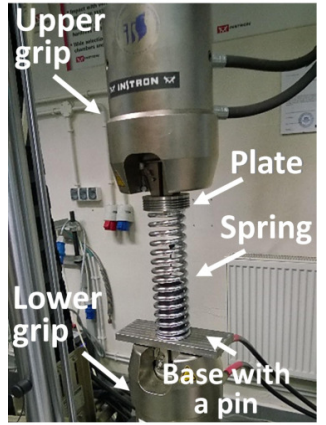

Fig. 6. Cylindrical (coil) spring on the test stand: a) reconfigured in a horizontal position, b) in a testing machine (8874 INSTRON) mounted vertically

Usually, the participation of two research teams leads to differences in the mounting of the test object, resulting from the variety of test stands (Figs. 6b, c). Thus, there may be a case 
in which the tested object will be examined in two different positions: horizontal (Fig. 6b) and vertical (Fig. 6c). In such experimental events, the same values of the preload should be ensured to minimize the influence of the test object mass on the result, especially in the case of its horizontal orientation (Fig.6b). At the same time, it should be indicated which of the mentioned spring positioning cases is the operational one (Fig. 6b). Regardless of the test stand used, marking should be carried out on its individual components, indicating the method of fixing, the system for applying the loading and measuring sensors (Fig. 6). In the case of mounting a spring, the same alignment with the direction of the force vector should be maintained and the value of the force determined, causing the initial stress in the tested object. In the case of the component from Figure $6 \mathrm{a}$, it was the value of $2 \mathrm{~N}$. During the test, in addition to the force value, the spring deflection should be recorded as a controlling parameter. For the tested object from Figure $6 \mathrm{a}$, the nominal value of the force at which the measurements were carried out was equal to $900 \mathrm{~N} \pm 3 \mathrm{~N}$ (using a mechanical actuator, Fig. 6b), and $900 \mathrm{~N} \pm 2.5 \mathrm{~N}$ (using the 8874 INSTRON testing machine, Fig. 6c).

In the assessment of the competences for the participants of the inter-laboratory comparison, the value " $t$ " was used to determine the spring deflection employed in the study of the significance of the difference between two mean values determined in the inter-laboratory test. It was based on the assumption of a normal distribution of a set with unknown standard deviations and with small specimen numerousness, below 122 . The $\mathrm{H}_{0}: \overline{X_{1}}=\overline{X_{2}}$ hypothesis and the related formula (1) were adopted. If the null hypothesis is true, then the statistic according to (1) has the t-Student distribution with $n_{1}+n_{2}-2$ degrees of freedom [24]

$$
t=\frac{\overline{X_{1}}-\overline{X_{2}}}{\sqrt{\frac{n_{1} S_{1}^{2}+n_{1} S_{2}^{2}}{n_{1}+n_{2}-2}\left(\frac{1}{n_{1}}+\frac{1}{n_{2}}\right)}}
$$

where: $\overline{X_{1}}$ and $\overline{X_{2}}$ - average values; $n_{1}$ - the number of measurements of test No. $1, n_{2}-$ the number of measurements in test No. 2; $S_{1}$ - estimator of the standard deviation of test No. 1; $S_{2}$ - estimator of the standard deviation of test No. 2 .

In the case of this type of comparison, the research hypothesis is of great importance. It was formulated as follows: mean values of deflection of the tested object obtained by participant No. 1 and participant 2 are the same. Due to the same number of measurement results (n), obtained by both participants of the inter-laboratory comparison, the number of degrees of freedom according to: $\mathrm{n}-1=3-1=2$ was used to read the $t_{\mathrm{gr}}$ value. The case of a different numerousness of measurement results would lead to the use of degrees of freedom determined by the expression: $n 1+n 2-2$.

Apart from the statistical analysis of the measurement results carried out using the formulas for the student's t-significance test, the $E_{n}$ number was determined using the guidelines of the PN-EN ISO IEC 17043: 2011 standard [25].

$$
E_{n}=\frac{\bar{X}_{Z 1}-\bar{X}_{Z 2}}{\sqrt{U_{Z 1}^{2}+U_{Z 2}^{2}}}
$$

where: $\bar{X}_{Z 1}$ is the average value of the result obtained by participant No. $1 ; \bar{X}_{Z 2}$ is the mean value of the result obtained by participant number $2 ; U_{Z 1}$ represents the mean value of the expanded uncertainty of the measurements made by participant number $1 ; U_{Z 2}$ represents the mean value of the expanded uncertainty of the measurements made by participant number 2 . 
The criterion for evaluating the value of the $E_{n}$ number was carried out according to the following text [25]:

$\left|E_{n}\right| \leq 1.0$ - shows a satisfactory result and does not require any additional treatment,

$\left|E_{n}\right|>1.0$ - indicates an unsatisfactory result and requires additional treatment.

\section{Results}

\subsection{Strength screw}

The results of the tensile tests of the strength screw material are presented by the stressstrain characteristics (Fig. 7) and mechanical parameters such as: Young's modulus (E), proportional limit (PL), elastic limit (EL), conventional yield point (YP), relative elongation after fracture (RE), relative reduction of area (RR), (Table 1). Apart from the values of the abovementioned mechanical parameters, their location on the tensile curves was marked, allowing for the graphical observation of differences between the values of parameters of the same type (Fig. 7). They were visible for the value of the conventional elasticity limit, yield point and ultimate tensile strength. Their explanation should be related to the slight differences in the material properties of the tested screws, but not to a significant technical disadvantage. The ultimate tensile strength values differed by no more than $40 \mathrm{MPa}$. In the case of differences in this mechanical parameter, the cause is related to the local initiation of a significant permanent deformation at the stage preceding the formation of the necking, the location of which directly affects the value of the relative elongation. Therefore, material fracture occurred at a $1.3 \%$ difference overall deformation values. It is worth emphasizing that in the case of the proportional limit value, the differences were small and did not exceed $10 \mathrm{MPa}$, giving the basis for the conclusion that the tested material had a stable level of stress related to the elastic response under loading. This behaviour is of particular engineering importance as it determines the stress level up to which the structural material can be loaded and unloaded, without the occurrence of macroand micro-scale permanent deformation.

Moreover, based on the tabular summary of the values of all the determined mechanical parameters (Tab.1), a 5\% difference in the values of the relative reduction of area can be noticed. It indicates the unequal behaviour of the material in a complex state of stress, in this critical state, followed by rapid development of damage leading to breaking the construction material. Nevertheless, in the case of the tested material, the range of the post-critical state is relatively large, falling within the range of stress values from 950 to $600 \mathrm{MPa}$, respectively, with values of total deformation associated with them as: $0.04 \%$ and $0.14 \%$.

(a)

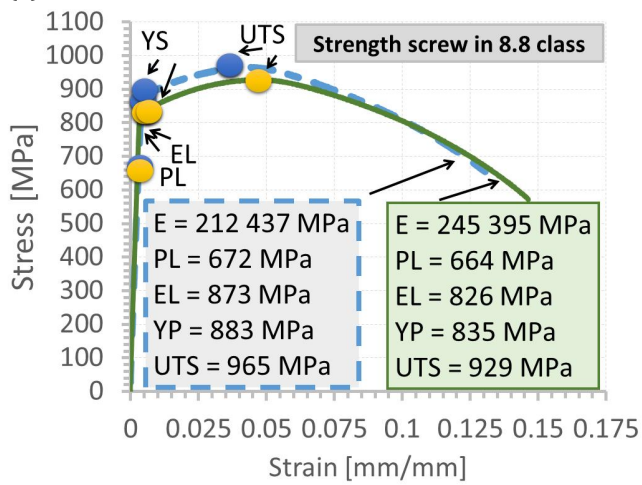

(b)

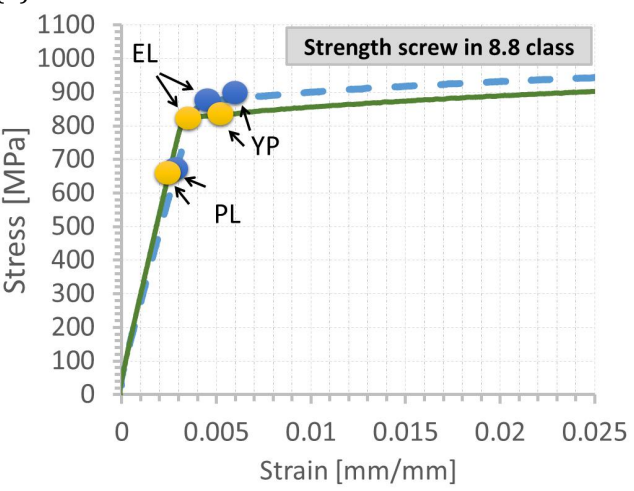

Fig. 7. Tensile characteristics of a steel screw material for the 8.8 strength class: up to fracturing (a), in the initial section of the curve containing a perfectly linear-elastic section and part of the strengthening region (b) 
The comparison of the obtained test results from the tensile tests (Fig. 7, Table 1) with the requirements of PN-EN ISO 898-1 [17] showed the high quality of the tested structural material of the strength screws. The values of all mechanical parameters, adopted for the purpose of comparison, significantly exceeded the minimum values of their equivalents included in the mentioned standard.

\section{Table 1}

Mechanical properties of the structural material for screws in 8.8 strength class; E - Young's modulus, PL - proportional limit, EL - elastic limit, YP - yield point, UTS - ultimate tensile strength, RR - relative reduction of area, RR - relative reduction of area

\begin{tabular}{|c|c|c|c|c|c|c|c|c|}
\hline $\begin{array}{l}\text { Specimen } \\
\text { number }\end{array}$ & $\begin{array}{l}\mathrm{E} \\
{[\mathrm{GPa}]}\end{array}$ & $\begin{array}{l}\mathrm{PL} \\
{[\mathrm{MPa}]}\end{array}$ & $\begin{array}{l}\mathrm{EL} \\
{[\mathrm{MPa}]}\end{array}$ & $\begin{array}{l}\text { YP } \\
{[\mathrm{MPa}]}\end{array}$ & $\begin{array}{l}\text { UTS } \\
{[\mathrm{MPa}]}\end{array}$ & $\begin{array}{l}\mathrm{RE} \\
{[\%]}\end{array}$ & $\begin{array}{l}\mathrm{RR} \\
{[\%]}\end{array}$ & UTS/YS \\
\hline 1 & 212 & 672 & 873 & 883 & 965 & 14.1 & 58.6 & 1.09 \\
\hline 2 & 245 & 664 & 826 & 835 & 929 & 15.4 & 53.6 & 1.11 \\
\hline Average values & 228 & 668 & 850 & 859 & 947 & 14.8 & 56.1 & 1.10 \\
\hline $\begin{array}{l}\text { Extended } \\
\text { measurement } \\
\text { uncertainty }\end{array}$ & \pm 12 & \pm 3 & \pm 17 & \pm 17 & \pm 13 & \pm 0.6 & \pm 1.8 & \\
\hline \multicolumn{4}{|c|}{$\begin{array}{l}\text { Minimum values (according to PN-EN ISO 898-1 } \\
\text { [17]) }\end{array}$} & 640 & 800 & 12 & 52 & 1.25 \\
\hline
\end{tabular}

\subsection{Technical spring}

Values of the compressive force and deflection of the spring with the mean values and expanded uncertainty are included in Table 2 . The obtained results indicated that the required force value was maintained at its assumed nominal level $(900 \mathrm{~N})$ with the extended measurement uncertainty not exceeding (RNP) $\pm 2 \mathrm{~N}$. Attention is drawn to the almost two-fold difference between the RNP of the test results carried out by both participants of the inter-laboratory comparison. They were the result of using different test stands. Participant No. 1 has used a multi-element measurement set with a horizontal positioning of the tested object (Fig. 6b), while participant No. 2 has employed a testing machine (with a compact and dedicated loadingmeasuring configuration), which enabled the spring to be tested in a vertical position (Fig. 6c). Nevertheless, the location of the tested object had no effect on the deflection values, leading to an almost equal value of the expanded measurement uncertainty.

The statistical results of the research are presented with the following values: limits of confidence intervals, relative precision, standardised residual and its mean value (Tab. 3 ). The measurement values determined were within the confidence intervals.

In the case of both participants of the inter-laboratory comparison, the relative precision of the force measurements was below $0.1 \%$. Deflection measurements had a precision not exceeding $0.6 \%$. Both participants of the trials obtained the rest of the standardized " $z$ " less than 2 (compliant with the standard quality criterion of the result according to PN-EN ISO / IEC 17043 [25]), which indicates the "satisfactory" result.

Table 2

Measurement results

\begin{tabular}{|l|l|l|l|l|}
\hline No. & \multicolumn{2}{|l|}{ Participant No. 1 } & Participant No. 2 \\
\hline $1 / 2 / 3$ & $\begin{array}{l}900.5 / 900.1 / 900.4 \\
{[\mathrm{~N}]}\end{array}$ & $\begin{array}{l}66.19 / 66.26 / 65.95 \\
{[\mathrm{~mm}]}\end{array}$ & $\begin{array}{l}900.8 / 900.3 / 900.5 \\
{[\mathrm{~N}]}\end{array}$ & $\begin{array}{l}66.43 / 66.24 / 66.44 \\
{[\mathrm{~mm}]}\end{array}$ \\
\hline Average value & 900.3 & 66.13 & 900.5 & 66.37 \\
\hline $\begin{array}{l}\text { Extended } \\
\text { measurement } \\
\text { uncertainty }\end{array}$ & \pm 1.7 & \pm 0.24 & \pm 0.8 & \pm 0.25 \\
\hline
\end{tabular}


The results of verifying the hypothesis of equality of mean deflection values are presented in Table 4. Its value was compared with the $t_{g r}$ limit value read from the Student's t-tables, with the significance level of 0.05 and the number of degrees of freedom 2 . The determined value of $t$ was smaller than the limit value of $t_{g r}$ from the Student's t-tables for $\alpha=0.05$ and $3-1=2$ degrees of freedom, which authorises the adoption of the formulated research hypothesis about the equality of mean values of deflection, determined by both participants of the comparative program.

Table 3

Statistical processing of the test results

\begin{tabular}{|c|c|c|c|c|c|}
\hline \multicolumn{6}{|c|}{--- Compressive force --- (Participant No. 1) } \\
\hline $\begin{array}{l}\text { Measurement } \\
\text { number }\end{array}$ & $\begin{array}{l}\text { Left side of the } \\
\text { confidence } \\
\text { interval at } \\
(1-\alpha)=0.95\end{array}$ & $\begin{array}{l}\text { Right side of the } \\
\text { confidence } \\
\text { interval at } \\
(1-\alpha)=0.95\end{array}$ & $\begin{array}{l}\text { Relative } \\
\text { precision } \\
{[\%]}\end{array}$ & $\begin{array}{l}\text { Standardised } \\
\text { residual "z" }\end{array}$ & $\begin{array}{l}\text { Mean value } \\
\text { of „z” }\end{array}$ \\
\hline $1 / 2 / 3$ & 899.7 & 901.0 & 0.05 & $\begin{array}{l}0.801 / 1.121 / \\
0.320\end{array}$ & 0.747 \\
\hline \multicolumn{6}{|c|}{--- Deflection --- (Participant No. 1) } \\
\hline $1 / 2 / 3$ & 65.64 & 66.63 & 0.53 & $\begin{array}{l}0.349 / 0.779 / \\
1.128\end{array}$ & 0.752 \\
\hline \multicolumn{6}{|c|}{--- Compressive force --- (Participant No. 2) } \\
\hline $\begin{array}{l}\text { Measurement } \\
\text { number }\end{array}$ & $\begin{array}{l}\text { Left side of the } \\
\text { confidence } \\
\text { interval at } \\
(1-\alpha)=0.95\end{array}$ & $\begin{array}{l}\text { Right side of the } \\
\text { confidence } \\
\text { interval at } \\
(1-\alpha)=0.95\end{array}$ & $\begin{array}{l}\text { Relative } \\
\text { precision } \\
{[\%]}\end{array}$ & $\begin{array}{l}\text { Standardised } \\
\text { residual "z" }\end{array}$ & $\begin{array}{l}\text { Mean value } \\
\text { of „z" }\end{array}$ \\
\hline $1 / 2 / 3$ & 899.8 & 901.3 & 0.06 & $\begin{array}{l}1.060 / 0.927 / \\
0.132\end{array}$ & 0.706 \\
\hline \multicolumn{6}{|c|}{--- Deflection --- (Participant No. 2) } \\
\hline $1 / 2 / 3$ & 66.03 & 66.71 & 0.37 & $\begin{array}{l}0.532 / 1.154 / \\
0.621\end{array}$ & 0.769 \\
\hline
\end{tabular}

Table 4

The result of the significance test for equality of mean values of the spring deflection

\begin{tabular}{|l|l|l|}
\hline No. & $\begin{array}{l}\text { The value of } \mathrm{t} \text { according } \\
\text { to the formula }(1)\end{array}$ & $\begin{array}{l}\text { Limit value of tgr from the Student's t-table } \\
\text { for } \mathrm{n}-1 \text { degrees of freedom }\end{array}$ \\
\hline 1 & 0.968 & $\mathrm{t}_{0.05 ; 2}=4.303$ \\
\hline
\end{tabular}

Value of the En, number calculated, based on the measurement results obtained by both participants of the inter-laboratory study, was equal to 0.68 . With regard to the evaluation criteria of the tested value, the obtained result indicates a satisfactory result and does not require any additional proceeding.

\section{Summary}

Tests with the use of specimens made of strength screws - as a reference object, made it possible to determine all mechanical parameters, both in the elastic and elastic-plastic ranges, including those necessary to evaluate the quality of the material examined and, at the same time, confirm the competence of the testing team. This type of experimental procedure can be successfully used in improving the competence of the research team. The research hypothesis 
concerning the equality of mean values of the spring deflection obtained by both groups of the inter-laboratory procedure was confirmed statistically $\left(t<t_{g r}\right)$, indicating the competences of the participants of the comparison in the mentioned type of test.

A significant increase in the competences of the research teams is possible by conducting tests with the use of reference objects and inter-laboratory tests.

\section{References}

[1] PN-EN ISO 6892-1, Metallic materials - Tensile test - Part 1: Test method at room temperature.

[2] PN-EN ISO 6892-2, Metallic materials - Tensile testing - Part 2: Method of test at elevated temperature.

[3] Szymczak T., Kowalewski Z.L., Brodecki A., Stand tests in the assessment of the fatigue life of automotive components, Technical Supervision 2020, 1, 26-34.

[4] Szymczak T., Brodecki A., Kowalewski Z.L., Lasota P., Experimental assessment of fatigue durability of steering rod tip, Motor Transport 2018, 2, 63-72.

[5] Szymczak T., Brodecki A., Makowska K., Kowalewski Z.L., Tow truck frame made of high strength steel under cyclic loading, Materials Today: Proceedings 2019, 12, 2, 207-212.

[6] Szymczak T., Kowalewski Z.L., Selected projects of specimens used in testing the mechanical properties of materials, Technical Supervision 2011, 2, 30-35.

[7] Kowalewski Z.L., Szymczak T., Strength tests of welded joints in elements of selected structures, XXIV NonDestructive Materials Research Seminar, Zakopane, Poland, 14-16 March 2018.

[8] Szymczak T., Cholewiński S., Sobolewski T., Strength and stand tests - as a tool for assessing the technical quality of materials and construction components related to road safety, Road Traffic Safety 2020, 3-4, 21-24.

[9] Kowalewski Z.L., Dietrich L., Kopeć M., Szymczak T., Grzywna P., Modern optical systems in mechanical tests structure, operation, applications, XXII Non-Destructive Materials Research Seminar, Zakopane, Poland, 2016.

[10] Brodecki A., Szymczak T., Kowalewski Z.L., Digital image correlation technique as a tool for kinematics assessment of structural components, Acta Mechanica et Automatica 2018, 12, 2, 101-104.

[11] Szymczak T., Investigations of material behaviour under monotonic tension using a digital image correlation system, Journal of Theoretical and Applied Mechanics 2018, 56, 3, 857-871.

[12] Niezgodziński M.E., Niezgodziński T., Strength of Materials, Scientific Publishing House PWN, Warszawa 2010.

[13] Kowalewski Z.L., Fundamentals for strength of materials, Printing House PW, 2010.

[14] Ganczarski A., Skrzypek J., Mechanics of modern materials, Publishing House of the Cracow University of Technology, Kraków 2013.

[15] Bijak-Żochowski M., Jaworski A., Krzęsiński G., Zagrajek T., Mechanics of materials and structures, tom I i II, OWPW, 2013.

[16] Niezgodziński M.E., Niezgodziński T., Equations, charts and strength tables, WNT, Warszawa 2017.

[17] PN-EN ISO 898-1, Mechanical properties of fasteners made of carbon steel and alloy steel - Part 1: Screws, screws and studs with specified property classes - Coarse thread and fine pitch thread.

[18] PN-EN ISO 3506-1, Fasteners - Mechanical properties of corrosion-resistant stainless steel fasteners - Part 1 : Screws, screws and studs with specified grades and property classes.

[19] Experimental Methods in Mechanics of Solids, edited W. Szczepiński, PWN, Warszawa 1984.

[20] Kocańda W., Fatigue Failure of Metals, WNT, Warszawa 1985.

[21] Kowalewski Z.L., Directions and perspectives for the development of strength tests, ITS, IPPT PAN, Warszawa 2008.

[22] Kowalewski Z.L., Modern strength tests, Biuro Gamma, Warszawa 2008.

[23] PN-EN ISO/IEC 17025, General requirements for the competence of testing and calibration laboratories.

[24] Sobczyk M., Statistics, Scientific Publisher PWN, Warszawa 2007.

[25] PN-EN ISO/IEC 17043; Conformity assessment - General requirements for proficiency testing.

\section{Doskonalenie jakości prowadzenia badań mechanicznych na przykładzie testów z wykorzystaniem obiektów odniesienia oraz porównań międzylaboaratoryjnych}

\section{STRESZCZENIE:}

Celem pracy jest zaprezentowanie postępowania badawczego dla doskonalenia wykonywania badań mechanicznych. W artykule przedstawiono wyniki badań pochodzące z prób mechanicznych zrealizowanych 
z udziałem obiektów odniesienia oraz będących udziałem porównania międzylaboratoryjnego. Zaprezentowano szczegóły techniki badawczej, dotyczącej określania parametrów mechanicznych śrub wytrzymałościowych oraz badania sprężyn technicznych. Zamieszczono charakterystykę rozciągania materiału śruby ze wskazaniem wszystkich niezbędnych parametrów mechanicznych istotnych dla praktyki inżynierskiej tj. z zakresu sprężystego oraz sprężysto-plastycznego. W przypadku sprężyny zaprezentowano wartości jej ugięcia, wynikające z kilkukrotnego obciążania do określonej wartości siły i następującego odciążania. Uzyskane wyniki badań odniesiono do cech własnych obiektu odniesienia oraz porównano wzajemnie z wykorzystaniem zagadnień statystyki matematycznej oraz wymagań normy dotyczącej badań biegłości. $\mathrm{W}$ efekcie potwierdzono kompetencje zespołów badawczych $\mathrm{w}$ zakresie wykonywania wymienionych rodzajów prób mechanicznych.

\section{SŁOWA KLUCZOWE:}

testy mechaniczne; porównania międzylaboratoryjne; polepszanie jakości; kompetencje 